Lihter, I., et al., 2022, Decrypting the polymetamorphic record of the Himalaya: Geology, https://doi.org/10.1130/G49467.1

\title{
Methods
}

Major and trace element geochemistry

Major element geochemistry of garnet in thin sections were acquired using Cameca SXFiveFE electron probe microanalyzer (EPMA) housed in the Fipke Laboratory for Trace Element Research (FiLTER) at the University of British Columbia, Okanagan (UBCO). Operating conditions for major element acquisition were $15 \mathrm{kV}, 20 \mathrm{nA}$, dwell time of $30 \mathrm{~s}$ for peak and $15 \mathrm{~s}$ for background, with focused beam size of $<1 \mu \mathrm{m}$. Oxide weight percent obtained from EPMA was converted to atom per formula unit (a.p.f.u.) based on the stoichiometric atoms of oxygens in mineral formula (120 - garnet). Almandine, grossular, pyrope and spessartine garnet endmembers were calculated using formulas:

almandine $=\mathrm{Fe}^{2+} /\left(\mathrm{Fe}^{2+}+\mathrm{Ca}+\mathrm{Mg}+\mathrm{Mn}\right) ;$ grossular $=\mathrm{Ca} /\left(\mathrm{Fe}^{2+}+\mathrm{Ca}+\mathrm{Mg}+\mathrm{Mn}\right) ;$ pyrope $=$ $\mathrm{Mg} /\left(\mathrm{Fe}^{2+}+\mathrm{Ca}+\mathrm{Mg}+\mathrm{Mn}\right) ;$ spessartine $=\mathrm{Mn} /\left(\mathrm{Fe}^{2+}+\mathrm{Ca}+\mathrm{Mg}+\mathrm{Mn}\right)$

Trace element geochemistry and mapping of garnet mounted in epoxy resin were acquired using Photon Machines Analyte 193 Excimer laser coupled with Agilent 8900 Triple Quadrupole Inductively Coupled Plasma-Mass Spectrometer (ICP-MS) also housed in FiLTER at UBCO. Garnets were mounted in epoxy, grinded, sanded and polished until cores were exposed. Operating conditions for garnet mapping and spot analysis were $100 \%$ laser energy, $8 \mathrm{~Hz}$ repetition rate and $6.78 \mathrm{Jcm}^{-2}$ fluence. Mapping line scan spot size of $29.6 \mu \mathrm{m}$ was used for KA007 and KA064 specimens, $39.4 \mu \mathrm{m}$ for KA031, $49.3 \mu \mathrm{m}$ for KA044 and $64.1 \mu \mathrm{m}$ in KA014 with selected analytes $\mathrm{Y}, \mathrm{Zr}, \mathrm{La}, \mathrm{Ce}$, $\mathrm{Gd}, \mathrm{Yb}$ and Lu. Garnet spot analysis used spot size of $29.6 \mu \mathrm{m}, 30 \mathrm{~s}$ ablation and $30 \mathrm{~s}$ background analysis, with selected analytes $\mathrm{P}, \mathrm{Y}$ and rare earth elements ( $\mathrm{La}, \mathrm{Ce}, \mathrm{Pr}$, $\mathrm{Nd}, \mathrm{Sm}, \mathrm{Eu}, \mathrm{Gd}, \mathrm{Tb}$, Dy, Ho, Er, Tm, Yb, Lu). For garnet mapping, NIST SRM 610 was used as an external reference material, while for trace element spot analysis, NIST SRM 612 and 610 were used as external primary and secondary reference material respectively. For both mapping and spot analysis, $\mathrm{Si}^{29}$ was used as an internal standard. Raw data was processed, and maps were visualized using lolite v.4.3 (Paton et al., 2011). 


\section{Monazite geochronology}

Monazite and xenotime inclusions in garnets mounted in epoxy resin were analyzed using a Photon Machines Analyte 193 Excimer laser coupled with $\mathrm{Nu}$ Instruments Nu Plasma Multicollector ICP-MS housed at University of California, Santa Barbara. Operating conditions were $4 \mathrm{~Hz}$ repetition rate, $1.7 \mathrm{Jcm}^{-2}$ laser fluence for $25 \mathrm{~s}$, and $8 \mu \mathrm{m}$ spot size, with details described in Cottle et al., 2013. The isotopes were normalized to '44069', while 'Bananeira' and 'Trebilcock' served as secondary reference materials. Geochronology plots were made using ChrontouR (Larson, 2020).

Nine repeat analyses of 'Bananeira' yielded a weighted mean ${ }^{206} \mathrm{~Pb} /{ }^{238} \mathrm{U}$ age of $522.6 \pm 5.7 \mathrm{Ma}$; mean square weighted deviation $(\mathrm{MSWD})=0.1(511.7 \pm 1.2 \mathrm{Ma}$ ID-TIMS age, Horstwood et al., 2016) and a weighted mean ${ }^{208} \mathrm{~Pb} /{ }^{232} \mathrm{Th}$ age of $500.0 \pm 6.3 \mathrm{Ma}$, MSWD $=0.1$ (497.6 $\pm 1.6 \mathrm{Ma}$ LA ICP-MS age, Kylander-Clark et al., 2013). Eight repeat analyses of 'Trebilcock' yielded a weighted mean ${ }^{206} \mathrm{~Pb} / 238 \mathrm{U}$ age of $279.8 \pm 3.2 \mathrm{Ma}$, MSWD $=0.8$ (ca. $279-285 \mathrm{Ma}$, Tomascak et al., 1996) and a weighted mean ${ }^{208} \mathrm{~Pb} /{ }^{232} \mathrm{Th}$ age of $261.4 \pm 3.5 \mathrm{Ma}$, MSWD = $0.2(263.7 \pm 1.0 \mathrm{Ma}$ LA ICP-MS age, Kylander-Clark et al., 2013). With monazite and xenotime inclusions being extremely small in size, generally $\sim 10 \mu \mathrm{m}$, most of the grains were ablated only partially. However, due to garnet grains having almost no $\mathrm{U}, \mathrm{Th}$, or $\mathrm{Pb}$ (Table S3) and which yielded no dates in points that missed the target, we therefore use dates of all ablated monazite and xenotime grains. As the aim is to constrain the portions based on Cenozoic dates, monazite dates are reported as ${ }^{208} \mathrm{~Pb} /{ }^{232} \mathrm{Th}$.

\section{Garnet geochronology}

Each rock specimen was crushed using a hydraulic press to enable individual picking of garnet grains. Complete, whole grains without cracks and fractures were selected for dissolution. Each garnet aliquot consists of one or more dissolved garnet grains. Chemical digestion and isotope analyses were conducted at the Pacific Center for Isotope and Geochemical Research, University of British Columbia. Garnet separates and whole-rock powders were weighed in screw-top PFA beakers following admixing of a ${ }^{176} \mathrm{Lu}-{ }^{180} \mathrm{Hf}$ isotope tracer. Garnet dissolution was done by cycling $\mathrm{HF}-\mathrm{HNO}_{3}-\mathrm{HClO}_{4}$ and $\mathrm{HCl}$ with intermittent solution dry-down. This method dissolves garnet without co- 
dissolving zircon (Lagos et al., 2007; Scherer et al., 2000). Whole-rock powders were dissolved in $\mathrm{HF}-\mathrm{HNO}_{3}$ kept at $180^{\circ} \mathrm{C}$ for 5 days in Parr® high-pressure digestion vessels. Solutions containing dissolved mineral and whole-rock chemical matrices were loaded onto pre-conditioned $12 \mathrm{~mL}$ Teflon $®$ columns containing Eichrom $\circledast \mathrm{Ln}$-spec resin, and Lu and $\mathrm{Hf}$ were isolated and purified using the methods of Münker et al. (2001). The Lu and $\mathrm{Hf}$ isotope measurements were carried out using a $\mathrm{Nu}$ Instruments Plasma I multicollector ICPMS (MC-ICPMS) instrument. The ${ }^{176} \mathrm{Lu} /{ }^{175} \mathrm{Lu}$ of unknowns was determined using ${ }^{176} \mathrm{Yb}$ interference corrections on the basis of a linear correlation between $\ln \left({ }^{176} \mathrm{Yb} /{ }^{171} \mathrm{Yb}\right)-\ln \left({ }^{174} \mathrm{Yb} /{ }^{171} \mathrm{Yb}\right)$, which was determined by replicate $\mathrm{Yb}$ standard measurements (Blichert-Toft et al., 2002). Hafnium mass bias was corrected assuming the exponential law and applying ${ }^{179} \mathrm{Hf} /{ }^{177} \mathrm{Hf}=0.7325$. All $\mathrm{Hf}$ isotope ratios are reported relative to ATI-475, which is an in-house $\mathrm{Hf}$ reference material that is isotopically identical to, and made from the same $\mathrm{Hf}$ metal ingots as, original JMC-475 $\left({ }^{176} \mathrm{Hf} /{ }^{177} \mathrm{Hf}=0.282160\right.$; Blichert-Toft et al., 1997). The external reproducibility of ATI-475 measured at concentrations typical of the garnet samples was $38 \mathrm{ppm}$. The external reproducibility (2 SD) of unknowns was estimated on the basis of the external reproducibility for ATI-475, which was measured at concentrations that bracketed those of the unknowns (Bizzarro et al., 2003). Total procedural $\mathrm{Hf}$ blanks during the course of the analytical session were

$8 \mathrm{pg}$ or lower. Isochron regressions and age calculations were done using Isoplot version 3.27 (Ludwig, 2003), applying $1.867 \times 10^{-11} \mathrm{yr}^{-1}$ for $\lambda^{176} \mathrm{Lu}$ (Scherer et al., 2001; Söderlund et al., 2004). All uncertainties are reported at the 2 SD level.

\section{Lu weighted garnet age calculation}

Due to the varying garnet grain shapes, the shape of each garnet was also considered. The surface area of each garnet was measured to obtain an average radius, which was then used to calculate the volume of each domain (Table S4).

A - surface area $\left(\mathrm{mm}^{2}\right)$

$\mathrm{R}$ - radius $(\mathrm{mm})$

$\mathrm{V}$ - volume $\left(\mathrm{mm}^{3}\right)$

AvLu - average Lu (ppm) 
Lucore - Lu in the core (\%)

Lurim - Lu in the rim (\%)

Rim_age - based on dates of monazite inclusions in the rims (Ma)

Core_age - estimated age of garnet core (Ma)

Equations used:

$$
\begin{gathered}
R=\sqrt{\frac{A}{\pi}} \\
V=R^{3} \times \pi \times \frac{4}{3} \\
V_{\text {rim }}=V_{\text {grain }}-V_{\text {core }} \\
\text { Lure }=100 \times \frac{A v L u_{\text {core }} \times V_{\text {core }}}{\left(A v L u_{\text {core }} \times V_{\text {core }}\right)+\left(A v L u_{\text {rim }} \times V_{\text {rim }}\right)} \\
\text { Core_age }=\frac{\text { LuHf_age }-\frac{\text { Lu } u_{\text {rim }}}{100 \times \text { Rim_age }}=100-L u_{\text {core }}}{\frac{L u_{\text {core }}}{100}}
\end{gathered}
$$

\section{Sampling coordinates}

KA007 Latitude: 27.1805 , Longitude: 87.4406

KA014 Latitude: 27.2942 , Longitude: 87.5265

KA031 Latitude: 27.4925 , Longitude: 87.7620

KA044 Latitude: 27.5976 , Longitude: 87.8004

KA064 Latitude: 27.8268 , Longitude: 87.8740 


\section{References}

Bizzarro, M., Baker, J.A., and Ulfbeck, D., 2003, A new digestion and chemical separation technique for rapid and highly reproducible determination of $\mathrm{Lu} / \mathrm{Hf}$ and $\mathrm{Hf}$ isotope ratios in geological materials by MS-ICP-MS. Geostandards Newsletter, 27(2), 133-145.

Blichert-Toft, J., Boyet, M., Télouk, P., and Albarède, F., 2002, 147Sm-143Nd and $176 \mathrm{Lu}-176 \mathrm{Hf}$ in eucrites and the differentiation of the HED parent body. Earth and Planetary Science Letters, 204(1-2), 167-181.

Blichert-Toft, J., Chauvel, C., and Albarède, F., 1997, Separation of Hf and Lu for highprecision isotope analysis of rock samples by magnetic sector-multiple collector ICP-MS. Contributions to Mineralogy and Petrology, 127, 248-260.

Cottle, J.M., Burrows, A.J., Kylander-Clark, A., Freedman, P.A., and Cohen, R.S., 2013, Enhanced sensitivity in laser ablation multi-collector inductively coupled plasma mass spectrometry: Journal of analytical atomic spectrometry, v. 28, p. 17001706.

Horstwood, M.S.A. et al., 2016, Community-Derived Standards for LA-ICP-MS U-(Th-) $\mathrm{Pb}$ Geochronology - Uncertainty Propagation, Age Interpretation and Data Reporting: Geostandards and Geoanalytical Research, v. 40, p. 311-332.

Kylander-Clark, A.R.C., Hacker, B.R., and Cottle, J.M., 2013, Laser-ablation splitstream ICP petrochronology: Chemical geology, v. 345, p. 99-112.

Lagos, M., Scherer, E.E., Tomaschek, F., Münker, C., Keiter, M., Berndt, J., and Ballhaus, C., 2007, High precision Lu-Hf geochronology of Eocene eclogitefacies rocks from Syros, Cyclades, Greece. Chemical Geology, 243(1-2), 16-35.

Larson, K.P., 2020, Geochronology Plotting Scripts in R: OSF, doi:10.17605/OSF.IO/P46MB.

Ludwig, K.R. (2003). Isoplot/Ex version 3.0. A geochronological toolkit for Microsoft Excel. Berkeley Geochronological Centre Spec. Pub., Berkeley, p.70.

Münker, C., Weyer, S., Scherer, E.E., and Mezger, K., 2001, Separation of high field strength elements ( $\mathrm{Nb}, \mathrm{Ta}, \mathrm{Zr}, \mathrm{Hf})$ and Lu from rock samples for MC-ICPMS measurements. Geochemistry, Geophysics, Geosystems, 2(12).

Paton, C., Hellstrom, J., Paul, B., Woodhead, J., and Hergt, J., 2011, Iolite: Freeware for the visualisation and processing of mass spectrometric data: Journal of analytical atomic spectrometry, v. 26, p. 2508-2518. 
Scherer, E. E., Cameron, K.L., \& Blichert-Toft, J., 2000, Lu-Hf garnet geochronology: Closure temperature relative to the $\mathrm{Sm}-\mathrm{Nd}$ system and the effects of trace mineral inclusions. Geochimica et Cosmochimica Acta, 64(19), 3413-3432.

Scherer, E. E., Münker, C., \& Mezger, K., 2001, Calibration of the Lutetium-Hafnium Clock. Science, 293, 683-688.

Söderlund, U., Patchett, P.J., Vervoort, J.D., \& Isachsen, C.E., 2004, The 176Lu decay constant determined by $\mathrm{Lu}-\mathrm{Hf}$ and $\mathrm{U}-\mathrm{Pb}$ isotope systematics of Precambrian mafic intrusions. Earth and Planetary Science Letters, 219(3-4), 311-324.

Tomascak, P.B., Krogstad, E.J., and Walker, R.J., 1996, U-Pb Monazite Geochronology of Granitic Rocks from Maine: Implications for Late Paleozoic Tectonics in the Northern Appalachians: The Journal of geology, v. 104, p. 185-195. 

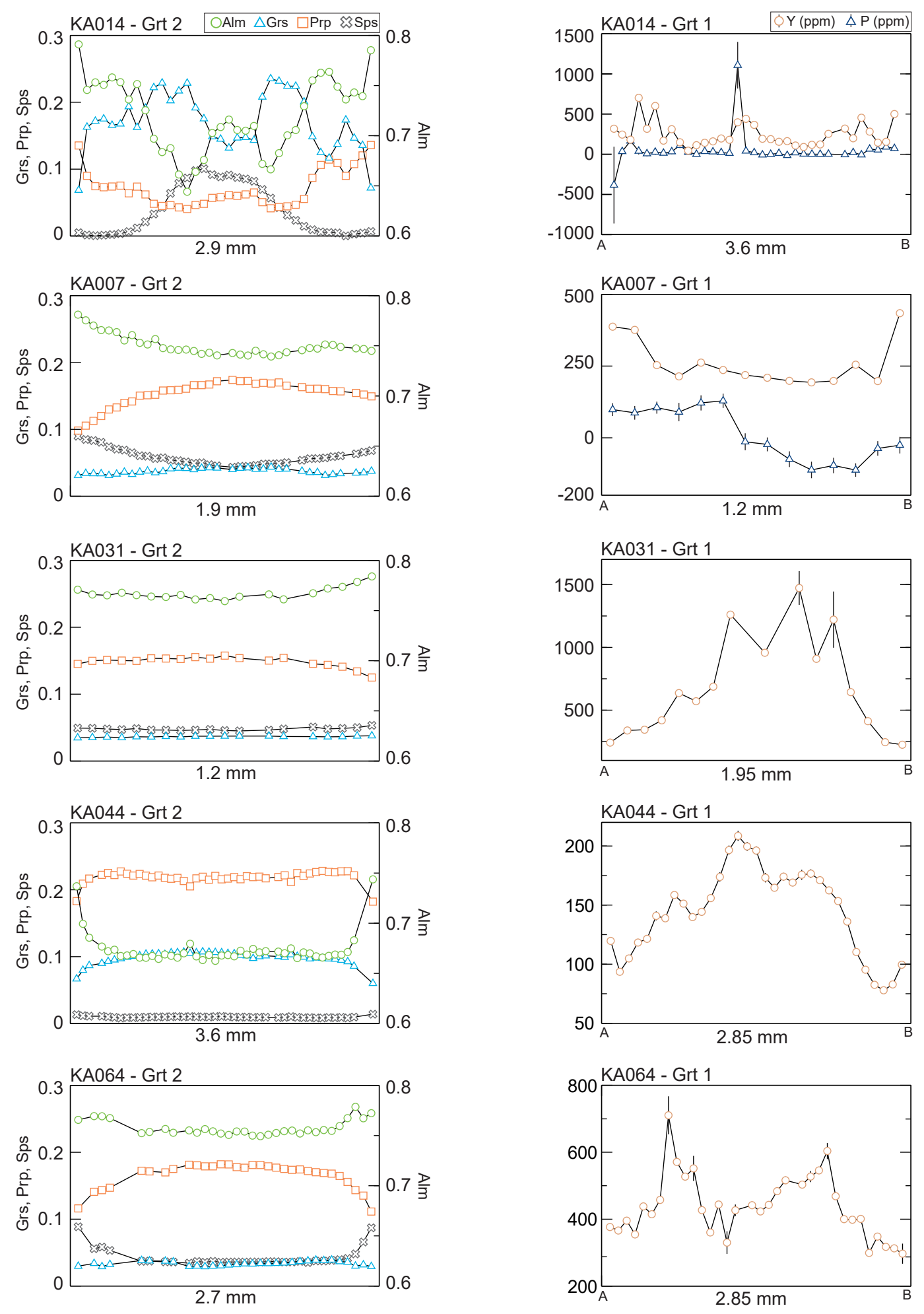

Figure S1. Garnet major element profiles.

Figure S2. Garnet trace element profiles for $P$ and $\mathrm{Y}$. The transect is marked on Figure 2. 

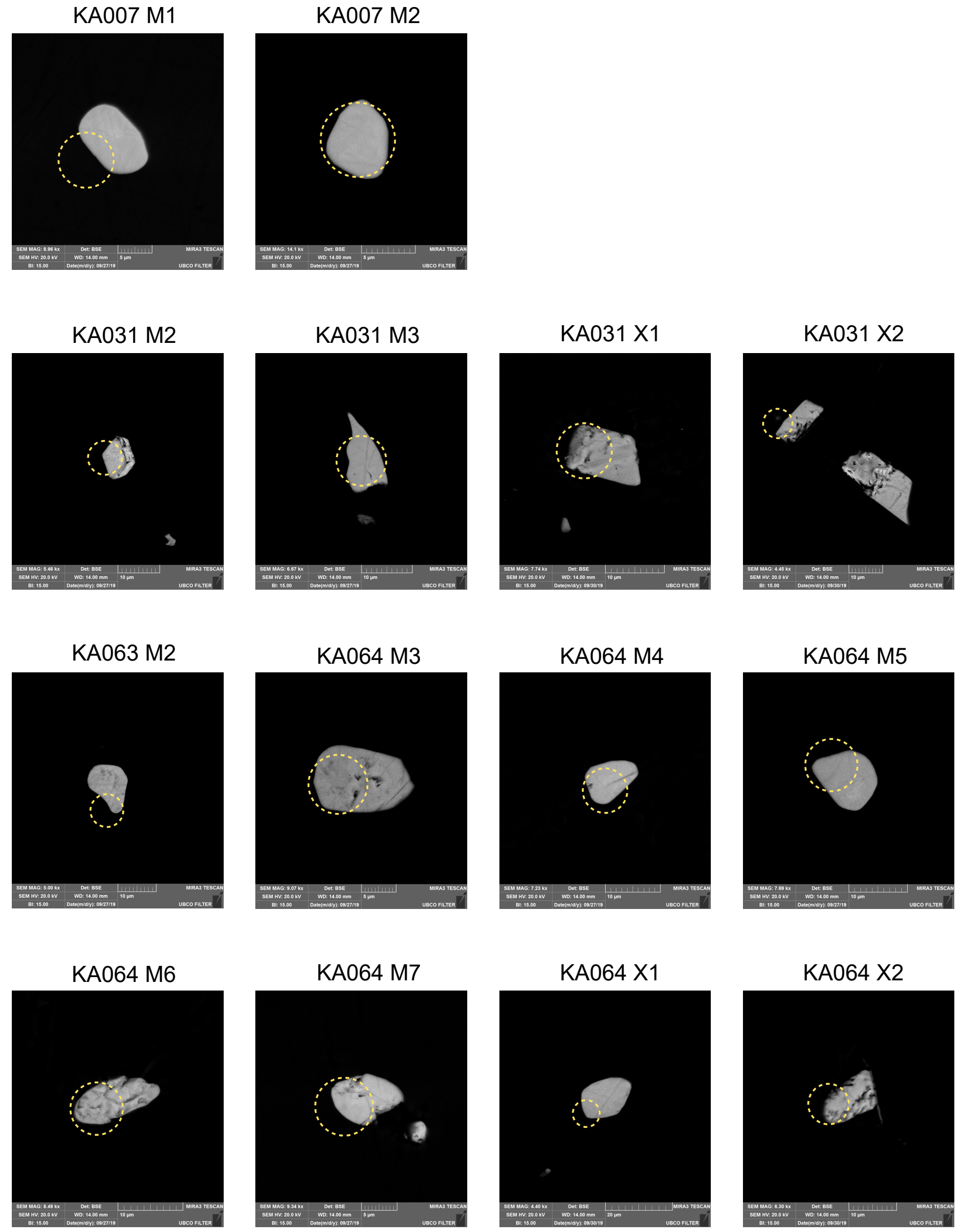

Figure S3. Backscattered electron images of analyzed monazites and xenotime grains. 

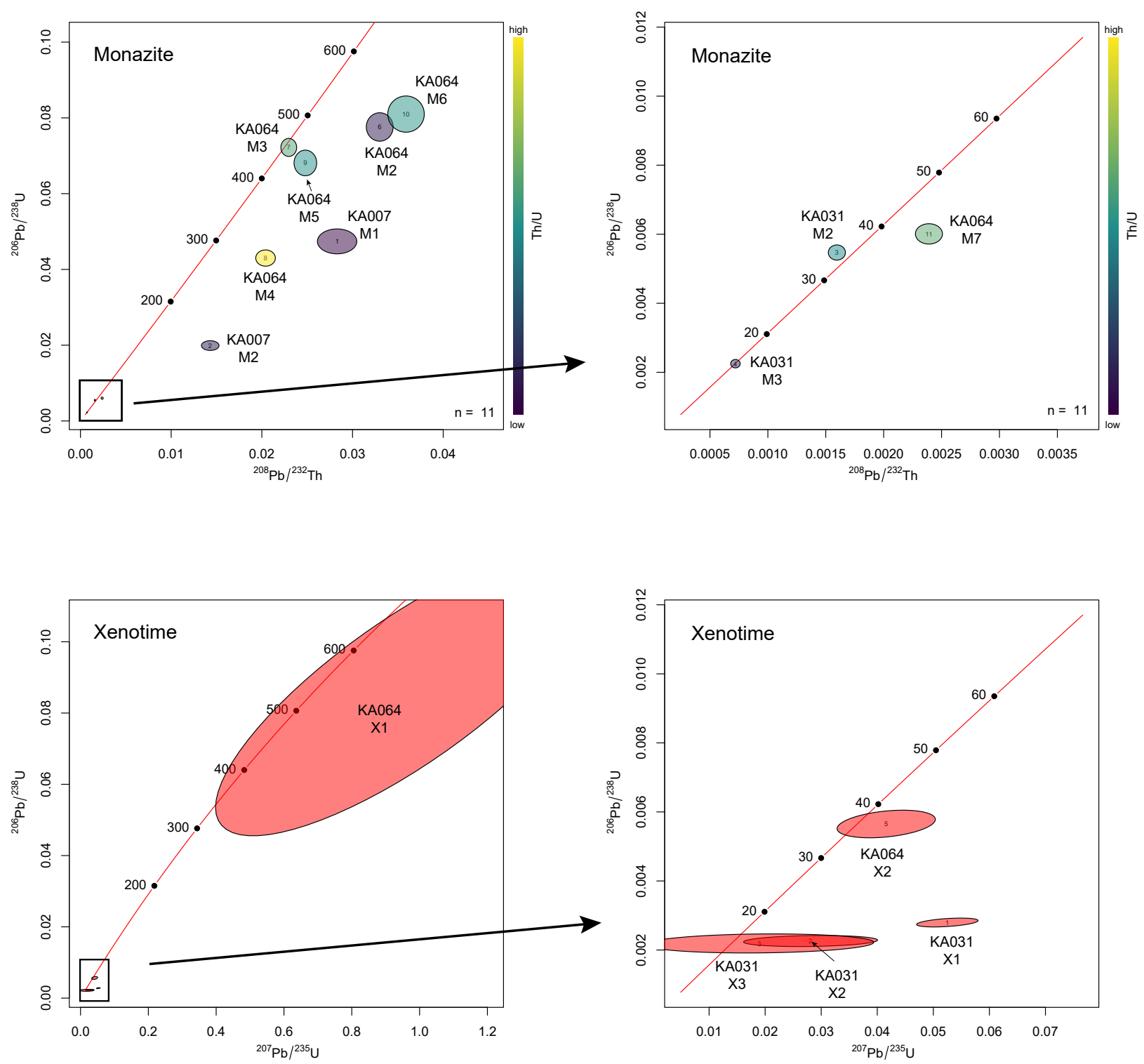

Figure S4. Concordia diagram ${ }^{206} \mathrm{~Pb} /{ }^{238} \mathrm{U} v{ }^{208} \mathrm{~Pb} /{ }^{232} \mathrm{Th}$ for monazite analyses (top panels), and ${ }^{206} \mathrm{~Pb} / 238 \mathrm{U}$ vs ${ }^{207} \mathrm{~Pb} / 235 \mathrm{U}$ for xenotime analyses (bottom panels). 

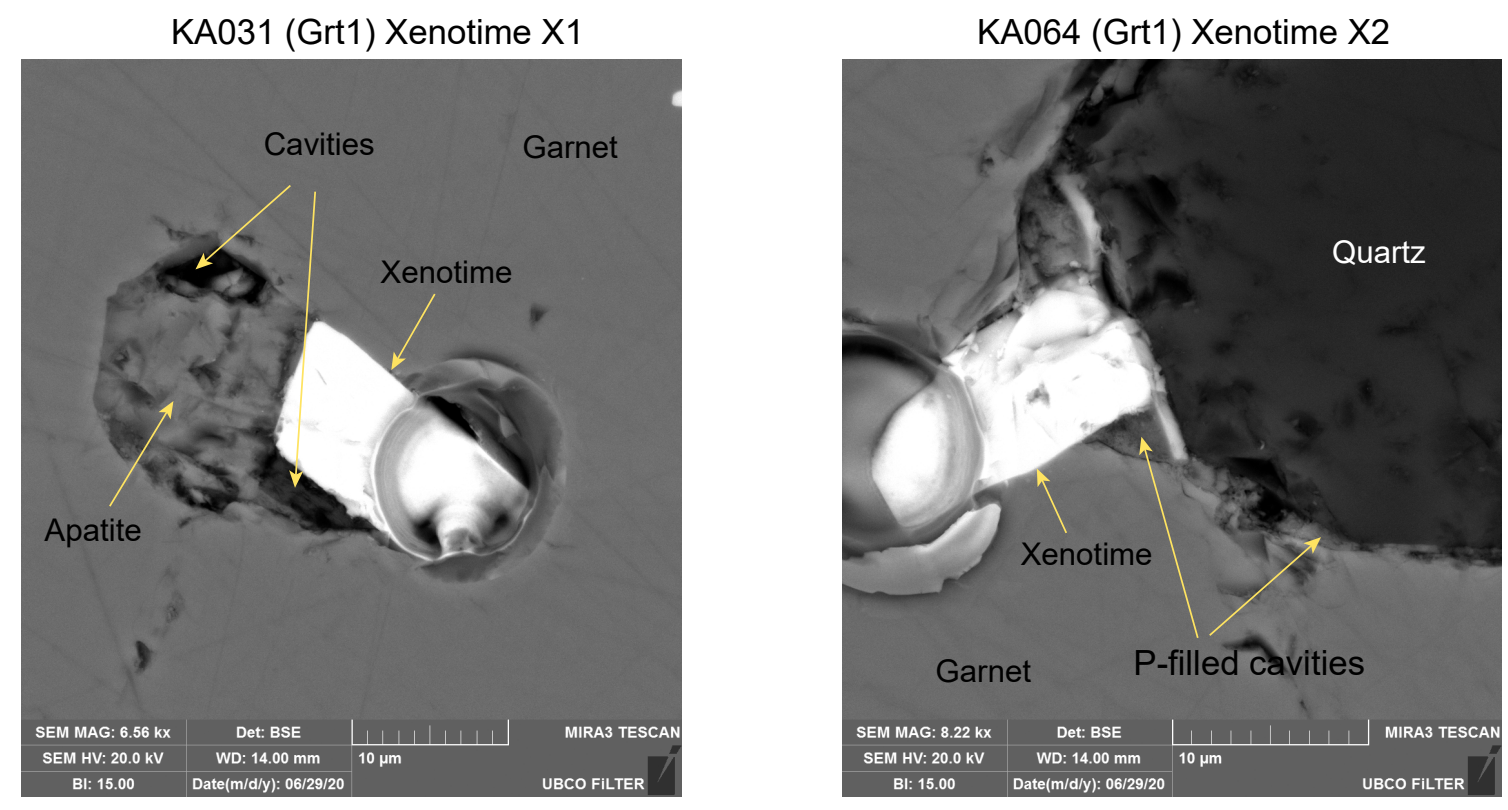

\section{KA064 (Grt1) Xenotime X2}
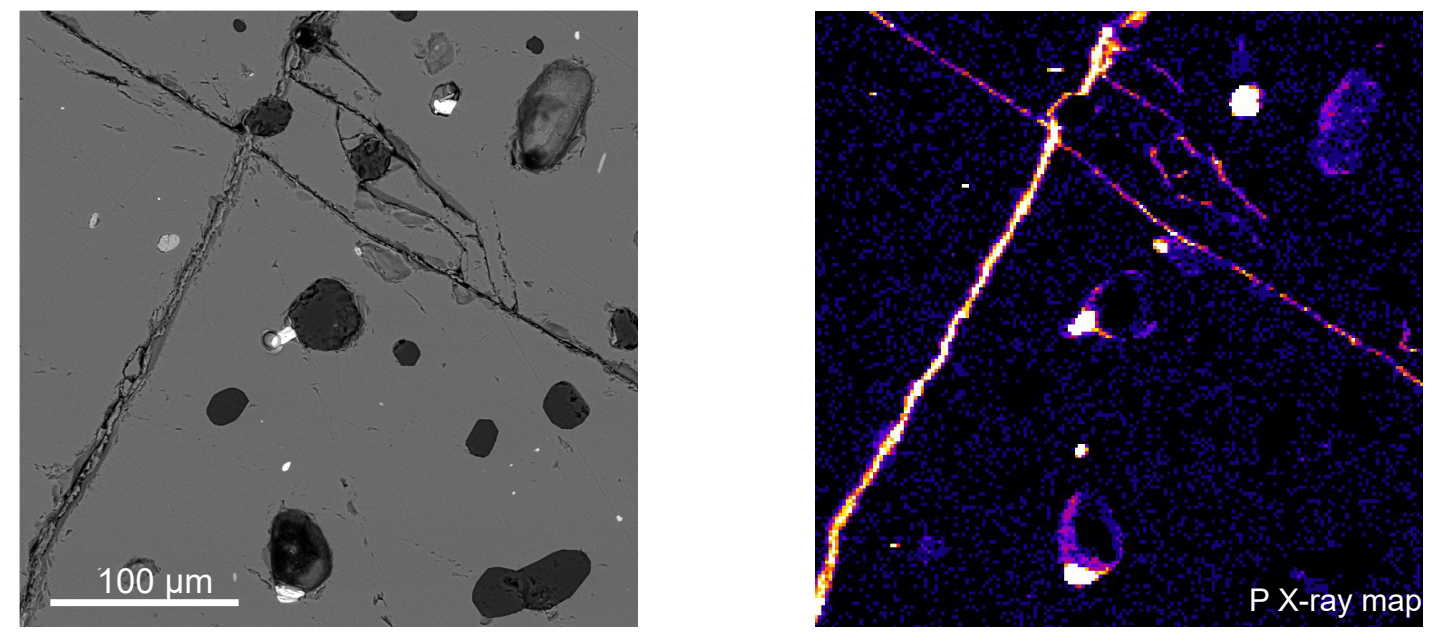

Figure S5. Backscattered electron images of excluded xenotime grains in specimens KA031 and KA064. Bottom right is phosphorus X-ray map. 